\title{
URGENSI OTONOMI KHUSUS BATAM DIKAITKAN DENGAN PELAKSANAAN MASYARAKAT EKONOMI ASEAN 2015
}

(The Importance of Special Autonomy of Batam According to Implementation
of ASEAN Economic Community 2015)

\author{
Muhammad Sapta Murti \\ Mahasiswa Program Doktoral IImu Hukum Universitas Padjajaran \\ Email: saptamurti@yahoo.com
}

Naskah diterima: 25 Agustus 2014; revisi: 8 September 2014; disetujui: 9 September 2014

\begin{abstract}
Abstrak
Batam saat ini merupakan daerah industri dan juga sebagai kawasan perdagangan bebas serta kawasan pelabuhan bebas. Peraturan perundang-undangan tersebut melahirkan 2 (dua) otoritas yang berwenang mengatur dan mengelola Batam, yaitu Badan Pengusahaan Batam dan Pemerintah Kota Batam. Keduanya memiliki wewenang berdasarkan peraturan perundang-undangan yang dalam pelaksanaannya sering tumpang tindih sehingga menghambat pembangunan di Pulau Batam. Di sisi lain, terdapat tantangan besar pada tahun 2015 dengan pelaksanaan ASEAN Economic Community (AEC 2015) sebagai realisasi integrasi ekonomi sesuai dengan Visi ASEAN 2020. Tulisan ini menganalisis mengenai urgensi otonomi khusus Batam dalam rangka penyelesaian persoalan tumpang tindih kewenangan terkait penyelenggaraan Batam serta dikaitkan dengan tantangan AEC 2015. Dengan menggunakan metode hukum normatif disimpulkan bahwa urgensi kekhususan Batam didasari oleh adanya alasan kekhususan Batam yang meliputi alasan filosofis, kesejarahanpolitis, yuridis, dan teoritis akademis. Kekhususan Batam meliputi substansi bidang politik dan pemerintahan, serta bidang perekonomian, pertanahan, dan penataan ruang. Melalui kekhususan Batam sebagai Pemerintah Provinsi Otonomi Khusus Batam, dualisme kelembagaan dan peraturan perundang-undangan di Batam akan menjadi kesatuan otoritas dan pengaturannya. Dengan demikian, cita-cita Batam menjadi daerah di Indonesia yang berada di jalur perdagangan internasional yang maju dapat tercapai serta menjadi bagian dari AEC 2015 yang berhasil.
\end{abstract}

Kata Kunci: kewenangan, asimetri, otonomi khusus

\section{Abstract}

Batam as an Industrial Zone, was also known as a free trade zone and free harbour zone. Based on enacted law there are 2 (two) agencies who has the authority to manage and administer Batam, which are Batam Indonesia Free Zone Authority (BIPZA) and The Local Government of Batam. In the implementation, both agencies has overlapping authority thereby sometimes the development of Batam are obstructed by this. On the other side there are big challenges in the year 2015, it is ASEAN Economic Community (AEC 2015) as an achievement of economic integration in line with the ASEAN Vision of 2020. This research tries to analize the critical issues about Batam Autonomy in order to solve the overlapping authority problems in Batam along with the AEC Challenges in 2015. Using normative legal method, it is concluded that special autonomy for Batam is urgent based on philosophical, historical, political, jurist and theoritical reasons. Special autonomy for Batam consist of politics and goverment field, economics, and land and space planning. Through the autonomy of Batam, it's expected that the dualism of institution and/or regulation will unite in one authority and regulation as well. Therefore, Batam's goal to be an advanced district in Indonesia which will be part of the international trade lines can be accomplished and Batam can be part of AEC 2015.

Keywords: asymmetry, authority, special autonomy 


\section{A. Pendahuluan}

Dalam konteks masa kini, pengelolaan dan pemanfaatan pulau-pulau di Indonesia menjadi suatu tantangan tersendiri bagi Pemerintah Indonesia. Karakteristik wilayah yang terpisahpisah berpengaruh pada koordinasi dan konektivitas antar pulau di Indonesia. ${ }^{1}$ Salah satu pulau yang memiliki peran strategis tersebut yaitu Pulau Batam. Pulau Batam merupakan salah satu pulau yang berada di Provinsi Kepulauan Riau. ${ }^{2}$ Secara historis pengelolaan Pulau Batam dilakukan oleh Perusahaan Negara Pertambangan Minyak dan Gas Bumi Nasional (PN Pertamina) ${ }^{3}$ (1970-1971); Badan Pimpinan ${ }^{4}$ (1971-1973); Otorita Batam ${ }^{5}$ (1973-2007); serta terakhir Badan Pengusahaan (2007-sekarang).

Berdasarkan Pasal 3 dan Pasal 4 Peraturan Pemerintah Nomor 46 Tahun 2007, semua aset Otorita Batam dialihkan menjadi aset Badan Pengusahaan, kecuali aset yang telah diserahkan kepada Pemkot Batam. Pegawai pada Otorita Batam dialihkan menjadi pegawai pada Badan Pengusahaan. Selain itu, hak pengelolaan atas tanah menjadi kewenangan
Otorita Batam. Hak pengelolaan atas tanah yang menjadi kewenangan Pemkot Batam yang berada di Kawasan Perdagangan Bebas dan Pelabuhan Bebas Batam beralih kepada Badan Pengusahaan sesuai dengan peraturan perundang-undangan. Lebih lanjut dalam Penjelasan Pasal 4 Peraturan Pemerintah Nomor 46 Tahun 2007 dinyatakan bahwa hak pengelolaan yang menjadi wewenang Pemkot Batam beralih kepada Badan Pengusahaan setelah terjadi pelepasan hak pengelolaannya dari Pemkot Batam.

Dalam implementasi pengelolaan Pulau Batam sebagai kawasan Perdagangan Bebas dan Pelabuhan Bebas terjadi ketidakharmonisan antara pengaturan pemerintahan daerah dan penataan ruang. ${ }^{6}$ Dengan lahirnya UndangUndang Nomor 22 Tahun 1999 tentang Pemerintah Daerah, wilayah Negara Kesatuan Republik Indonesia dibagi dalam daerah provinsi, daerah kabupaten, dan daerah kota yang bersifat otonom. Berdasarkan undang-undang tersebut maka seluruh wilayah Indonesia sudah terbagi habis ke dalam wilayah-wilayah yang memiliki

Deloitte Access Economic, "The Connected Archipelago: The Role of the Internet in Indonesia's Economic Development", (Desember 2011), hlm. 3.

2 Berdasarkan hasil verifikasi Tim Nasional Pembakuan Nama Rupabumi yang terdiri atas Kementerian Dalam Negeri, Kementerian Keluatan dan Perikanan, Badan Koordinasi Survey dan Pemetanaan Nasional (Bakorsurtanal), Dinas Hidro Oseanografi TNI Angkatan Laut, dan Dinas Topografi TNI Angkatan Darat diperoleh data bahwa Kepulauan Riau terdiri atas 2408 pulau.

3 Lihat KePeraturan Pemerintahres Nomor 65 Tahun 1970.

$4 \quad$ Lihat Pasal 5 KePeraturan Pemerintahres Nomor 74 Tahun 1971.

5 Lihat Pasal 4 ayat (1) KePeraturan Pemerintahres Nomor 41 Tahun 1973.

6 Bentuk ketidakharmonisan tersebut secara faktual dapat dilihat dengan adanya permohonan gugatan uji materil atas Undang-Undang Nomor 44 Tahun 2007 ke Mahkamah Konstitusi. Pemohon menganggap bahwa Undang-Undang Nomor 44 Tahun 2007 memiliki persoalan yuridis penetapan kawasan Perdagangan Bebas dan Pelabuhan Bebas Kota Batam karena akan mempengaruhi penyelenggaraan pemerintahan dan pembangunan di Kota Batam sebagai daerah otonom. Payung hukum penetapan Kawasan Perdagangan Bebas dan Pelabuhan Bebas adalah dengan Perpu Nomor 1 Tahun 2007 yang ditetapkan sebagai Undang-Undang Nomor 44 Tahun 2007, berlaku umum secara nasional, sementara payung hukum penyelenggaraan pemerintahan dan pembangunan di Kota Batam adalah Undang-Undang Nomor 53 Tahun 1999 yang berlaku khusus (lex specialis) bagi Kota Batam. Namun, dalam Putusan Nomor 29/PUU-XI/2013, Mahkamah Konstitusi menolak permohonan Pemohon. 
kewenangan-kewenangan tertentu. Sebagai pelaksanaan otonomi daerah tersebut, Pulau Batam pun ditetapkan menjadi Kota Batam sesuai dengan Undang-Undang Nomor 53 Tahun 1999 tentang Pembentukan Kabupaten Pelalawan, Kabupaten Rokan Hulu, Kabupaten Rokan Hilir, Kabupaten Siak, Kabupaten Karimun, Kabupaten Natuna, Kabupaten Kuantan Singingi, dan Kota Batam.

Lahirnya Kota Batam menimbulkan tumpang tindih kewenangan antara Pemkot Batam dengan Badan Pengusahaan. Eksistensi kedua lembaga yang didukung oleh struktur ${ }^{7}$ dan substansi hukum $^{8}$ yang berbeda menyebabkan kebijakan pengelolaan Pulau Batam tidak harmonis. Keberadaan Badan Pengusahaan yang didahului oleh Otorita Batam berdasarkan Keputusan Presiden Nomor 41 Tahun 1973 dan memiliki kewenangan untuk melakukan pengelolaan Pulau Batam dan semakin diperkuat dengan lahirnya Undang-Undang Nomor 36 Tahun 2000 sebagaimana telah diubdah dengan Keputusan Presiden Nomor 44 Tahun 2007, serta Peraturan Pemerintah Nomor 46 Tahun 2007 sebagaimana telah diubah dengan Peraturan Pemerintah Nomorr 5 Tahun 2011 secara vis a vis dengan Undang-Undang Nomor 22 Tahun 1999 sebagaimana telah diubah dengan UndangUndang Nomor 32 Tahun 2004 serta UndangUndang Nomor 53 Tahun 1999.

Salah satu masalah yang sampai saat ini belum terselesaikan yaitu kepastian hukum tentang status hak atas tanah hasil reklamasi pantai di Pulau Batam. Hak atas tanah tersebut terkait dengan hak pengelolaan atas tanah yang dimiliki oleh Badan Pengusahaan. Sebagaimana diatur dalam Keputusan Presiden Nomor 41 Tahun 1973, Otorita Batam (sekarang Badan Pengusahaan) mempunyai hak pengelolaan tanah Pulau Batam. Sesuai dengan Bab Ketentuan Peralihan Pasal 4 Peraturan Pemerintah Nomor 46 Tahun 2007, hak pengelolaan atas tanah yang menjadi kewenangan Otorita Batam dan hak pengelolaan atas tanah yang menjadi kewenangan Pemkot Batam yang berada di Kawasan Perdagangan Bebas dan Pelabuhan Bebas Batam beralih kepada Badan Pengusahaan. Berdasarkan pasal 4 Peraturan Pemerintah Nomor 46 Tahun 2007 yang berada dalam ketentuan peralihan maka semua hak pengelolaan atas tanah yang ada sebelum Peraturan Pemerintah Nomor 46 tahun 2007 beralih dari Pemkot Batam ke Badan Pengusahaan melalui mekanisme pelepasan hak. Dengan berlakunya Peraturan Pemerintah Nomor 46 Tahun 2007, tidak ada lagi hak pengelolaan atas tanah yang diberikan kepada selain Badan Pengusahaan.

Hak pengelolaan atas tanah tersebut menjadi persoalan baru di wilayah pantai atau pesisir Pulau Batam yang mengalami reklamasi pantai ${ }^{9}$. Reklamasi menimbulkan sengketa kewenangan antara Badan Pengusahaan dengan Pemkot Batam, khususnya mengenai penagihan atas Uang Wajib Tahun Otorita (selanjutnya disingkat UWTO) oleh Badan Pengusahaan atas lahan

\footnotetext{
Struktur hukum ialah perangkat (organ, misalnya legislator dan penegak hukum) yang membentuk dan menjalankan (menegakkan) peraturan perundang-undangan.

Subtansi hukum ialah produk peraturan perundang-undangan.

9 Reklamasi adalah kegiatan yang dilakukan oleh orang dalam rangka meningkatkan manfaat sumber daya lahan ditinjau dari sudut lingkungan dan sosial ekonomi dengan cara pengurugan, pengeringan lahan atau drainase. Lihat Pasal 1 angka 23 Undang-Undang Nomor 27 Tahun 2007.
} 
hasil reklamasi pantai, ${ }^{10}$ batas-batas wilayah perdagangan bebas dan pelabuhan bebas, serta pengaruhnya terhadap insentif fiskal. Insentif yang dimaksud, diberikan kepada pihak lain oleh Badan Pengusahaan yang berada dalam kawasan perdagangan bebas dan pelabuhan bebas.

Sengketa timbul karena dualisme kewenangan serta perbedaan persepsi terhadap peraturan. Badan Pengusahaan berpendapat bahwa berdasarkan Peraturan Pemerintah Nomor 46 Tahun 2007, Keputusan Presiden Nomor 41 Tahun 1973, dan Keputusan Menteri Dalam Negeri Nomor 43 Tahun 1977 tentang Pengelolaan dan Penggunaan Tanah di Daerah Industri Pulau Batam, serta Peraturan Pemerintah Nomor 6 Tahun 2011 tentang Pengelolaan Keuangan Pada Badan Pengusahaan Kawasan Perdagangan Bebas dan Pelabuhan Bebas Batam, memberikan kewenangan (hak) kepada Otorita Batam (sekarang Badan Pengusahaan) termasuk untuk memungut UWTO terhadap lahan yang dimohonkan oleh pemohon atas pemanfaatan lahan hasil reklamasi di Pulau Batam. Begitu pula di dalam Undang-Undang Nomor 36 Tahun 2000 diatur bahwa dalam pemberian insentif fiskal hanya dapat dilakukan di dalam kawasan perdagangan bebas dan pelabuhan bebas yang hanya dapat dilakukan oleh Badan Pengusahaan. Dengan demikian, untuk mendapatkan hakhak tersebut maka tanah hasil relamasi pantai di Pulau Batam merupakan hak pengelolaan atas tanah Badan Pengusahaan yang termasuk wilayah kerja Badan Pengusahaan.

Sementara itu, menurut Undang-Undang Nomor 32 Tahun 2004, Pemkot Batam memiliki kewenangan bidang pemerintahan, termasuk kewenangan wajib kecuali bidang politik, luar negeri, pertahanan keamanan, peradilan, moneter dan fiskal, agama serta kewenangan bidang lain. Kewenangan wajib terdiri atas pekerjaan umum, kesehatan, pendidikan dan kebudayaan, pertanian, perhubungan, industri dan perdagangan, penanaman modal, lingkungan hidup, pertanahan ${ }^{11}$, koperasi, dan tenaga kerja yang mengakibatkan bahwa bidang pertanahan merupakan kewenangan Pemkot Batam. Pasal 14 Undang-Undang Nomor 32 Tahun 2004 mengatur bahwa urusan wajib yang menjadi kewenangan pemerintahan daerah untuk kabupaten/kota merupakan urusan yang berskala kabupaten/kota meliputi antara lain pelayanan pertanahan. Selain itu, Pemkot

$10 \quad$ Perencanaan dari Reklamasi pantai menurut Undang-Undang Nomor Tahun 27 tahun 2007 tentang wilayah pesisir pulau-pulau kecil harus memperhatikan: Keberlanjutan dari kehidupan dan penghidupan masyarakat; Keseimbangan antara kepentingan pemanfaatan dan kepentingan pelestarian fungsi lingkungan pulau-pulau kecil; Persyaratan teknis, pengambilan, pengerukan dan penimbunan material. Perencanaan dari reklamasi diatur dengan Peraturan Pemerintah dalam Pasal 11 disebutkan bahwa penyusunan rencana induk dari reklamasi harus memperhatikan kepemilikan dan penguasaan lahan. Salah satunya adalah tentang status tanah hasil reklamasi tersebut.

11 Kewenangan urusan pemerintahan bidang pertanahan dalam lampiran PERATURAN PEMERINTAH Nomor 38 Tahun2007, ada 9 (sembilan) Subbidang kewenangan Pemerintah Kabupaten/Kota di bidang pertanahan, yaitu: Sub Bidang Izin Lokasi; Sub Bidang Pengadaan tanah untuk kepentingan umum; Penyelesaian Sengketa Tanah Garapan; Penyelesaian Masalah Ganti Kerugian dan Santunan Tanah untuk Pembangunan; Penetapan Subyek dan obyek Redistribusi Tanah serta ganti Kerugian Tanah Kelebihan Maksimum dan Tanah Absentee; Penetapan tanah Ulayat; Pemanfaatan dan Penyelesaian Masalah Tanah Kosong; Izin Membuka Tanah; serta Perencanaan Penggunaan Tanah wilayah Kabupaten/Kota. 
Batam berpedoman pada Pasal 16 ayat (4) Peraturan Presiden Nomor 122 Tahun 2012 tentang Reklamasi di Wilayah Pesisir dan PulauPulau Kecil yang mengatur bahwa gubernur dan bupati/walikota memberikan izin lokasi dan izin pelaksanaan reklamasi dalam wilayah sesuai dengan kewenangannya. Pemkot Batam berpendapat bahwa wilayah Pulau Batam merupakan wilayah kewenangannya, sehingga reklamasi pantai yang dilakukan oleh Pemkot Batam telah sesuai dengan Peraturan Presiden Nomor 122 Tahun 2012 tentang Reklamasi di Wilayah Pesisir dan Pulau-Pulau Kecil, sehingga hasil reklamasi pantai tersebut yang berupa tanah dapat dimohonkan hanya dengan hak pengelolaan atas tanah oleh Pemkot Batam.

Di sisi lain permasalahan dalam negeri tersebut sepatutnya sudah tidak menjadi persoalan lagi dalam konteks AEC 2015. AEC 2015 yang ditujukan untuk mendorong efisiensi dan daya saing ekonomi kawasan ASEAN yang tercermin dalam 4 (empat) hal, yaitu: ${ }^{12}$ (1) ASEAN sebagai aliran bebas barang, bebas jasa, bebas investasi, bebas tenaga kerja terdidik, dan bebas modal; (2) ASEAN sebagai kawasan dengan daya saing tinggi; (3) ASEAN sebagai kawasan dengan pengembangan ekonomi yang merata dengan elemen pengembangan usaha kecil menengah, dan (4) ASEAN sebagai kawasan terintegrasi. Dalam konteks Batam, 4 (empat) hal tersebut harus mau tidak mau, suka ataupun tidak suka, harus diterapkan dengan segala persoalan tumpang tindih kewenangan dan regulasi yang ada di Batam. Padahal Batam merupakan asset yang luar biasa dalam upaya pengembangan perekonomian daerah, nasional, bahkan kawasan ASEAN mengingat posisi strategis Batam dalam jalur ekonomi ASEAN.

Dengan berbagai persoalan sebagaimana diuraikan di atas, terlihat tumpang-tindihnya kewenangan antara Badan Pengusahaan dan Pemkot Batam serta akan berpengaruh terhadap pelaksanaan AEC 2015 bagi Batam. Secara substansi hukum antara Pemkot Batam dan Badan Pengusahaan terjadi benturan, baik pengaturan Pulau Batam dalam kerangka daerah industri dan kemudian berkembang menjadi kawasan perdagangan bebas dan pelabuhan bebas, maupun dalam kerangka pengaturan otonomi daerah. Kewenangan tersebut berimplikasi pada tidak harmonisnya penyelenggaraan Pulau Batam karena terjadinya dualisme kelembagaan yang mengelolanya sehingga hal tersebut akan berdampak pada masyarakat secara umum.

Berdasarkan latar belakang masalah tersebut maka penulis akan melakukan analisis mengenai "Urgensi Otonomi Khusus Batam Dikaitkan Dengan Pelaksanaan ASEAN Economic Community 2015" sebagai salah satu solusi dalam penyelesaian tumpang tindih kewenangan dan peraturan perundangundangan di Pulau Batam dan pengaruh positif atas pelaksanaan AEC 2015 bagi Batam. Tulisan ini akan menganalisis mengenai bagaimanakah gambaran otonomi asimetri Batam, alasan Kekhususan Batam, serta urgensi otonomi khusus di Batam dikaitkan dengan AEC 2015.

\footnotetext{
12 Kementerian Perdagangan RI, Menuju ASEAN Economic Community 2015, hlm. 51-71.
} 


\section{B. Metode Penelitian}

Berdasarkan permasalahan diatas, penelitian ini merupakan suatu penelitian yuridis normatif ${ }^{13}$. Data yang ada dihubungkan satu sama lain melalui studi kepustakaan (library research), dikaji dan diinterpretasi dan dianalisa untuk selanjutnya ditarik kesimpulannya. Metode penelitian yuridis normatif adalah penelitian yang mengacu kepada normanorma hukum yang terdapat dalam peraturan perundang-undangan, konvensi internasional, perjanjian internasional dan putusan-putusan pengadilan ${ }^{14}$. Data melalui internet berupa artikel dan penelitian terdahulu juga studi kepustakaan dianalisa melalui studi dokumen yang berkaitan dengan permasalahan yang diteliti.

\section{Pembahasan}

\section{Otonomi Asimetri Batam}

Secara konstitusional, acuan penyelenggaraan pemerintahan daerah terdapat dalam Pasal 18 UUD NRI 1945. Pengaturan wewenang antara pemerintah pusat dan pemerintah daerah diperjelas dalam Pasal 18A UUD NRI 1945. Pasal ini mengatur bahwa hubungan wewenang antara pemerintah pusat dan pemerintahan daerah provinsi, kabupaten, dan kota, atau antara provinsi dan kabupaten dan kota, diatur dengan undang-undang dengan memperhatikan kekhususan dan keragaman daerah. UUD NRI Tahun 1945 telah mengatur pula mengenai kekhususan dan keistimewaan daerah-daerah di Indonesia. Hal tersebut sebagaimana tertuang dalam Pasal 18B UUD NRI 1945 yaitu bahwa negara mengakui dan menghormati satuansatuan pemerintahan daerah yang bersifat khusus atau bersifat istimewa yang diatur dengan undang-undang. Dasar konstitusional tersebut menjadi landasan yuridis pelaksanaan otonomi daerah di Indonesia. Bahkan mengenai kekhususan dan keistimewaan, UUD NRI 1945 pun menjamin pengakuan dan penghormatan atas satuan-satuan pemerintah daerah yang bersifat khusus atau istimewa. Otonomi bersifat seragam (simetri) maupun tidak seragam karena kekhususan atau keistimewaan (asimetri). ${ }^{15}$ Otonomi kepada daerah otonom ${ }^{16}$ pun tidak serta merta dilaksanakan secara simetri. Dalam pengertian otonomi daerah terkandung unsur kemampuan untuk mewujudkan apa-apa yang menjadi tugas, hak dan wewenang serta tanggungjawabnya memperhatikan, mengurus, dan mengatur rumah tangga sendiri. ${ }^{17}$

13 Soerjono Soekanto dan Sri Mamuji, Penelitian Hukum Normatif, Suatu Tinjauan Singkat (Jakarta: CV Rajawali, 1990), hlm. 15.

14 C.F.G Sunariyati Hartono, Penelitian Hukum di Indonesia Pada Akhir Abad ke-20, (Bandung: Alumni, 1994), hlm. 143.

15 Desentralisasi adalah penyerahan wewenang pemerintahan oleh Pemerintah kepada daerah otonom untuk mengatur dan mengurus urusan pemerintahan dalam sistem Negara Kesatuan Republik Indonesia. Lihat Pasal 1 angka 7 Undang-Undang Nomor 32 Tahun 1999.

16 Daerah otonom, selanjutnya disebut daerah, adalah kesatuan masyarakat hukum yang mempunyai batas-batas wilayah yang berwenang mengatur dan mengurus urusan pemerintahan dan kepentingan masyarakat setempat menurut prakarsa sendiri berdasarkan aspirasi masyarakat dalam sistem Negara Kesatuan Republik Indonesia. (Lihat Pasal 1 angka 6 Undang-Undang Nomor 32 Tahun 2004).

17 Ateng Syafrudin, Titik Berat Otonomi Daerah Pada Daerah Tingkat II dan Perkembangannya, (Bandung: Mandar Maju, 1992), hlm. 61. 
Secara yuridis, pelaksanaan otonomi daerah tertuang secara organik dalam UndangUndang Nomor 32 Tahun 2004. Undang-udang ini mengartikan otonomi daerah sebagai hak, wewenang, dan kewajiban daerah otonom untuk mengatur dan mengurus sendiri urusan pemerintahan dan kepentingan masyarakat setempat sesuai dengan peraturan perundang-undangan. ${ }^{18}$ Otonomi daerah akan menghasilkan daerah otonom berupa sebuah kesatuan masyarakat hukum yang mempunyai batas-batas wilayah, serta berwenang mengatur dan mengurus urusan pemerintahan dan kepentingan masyarakat setempat menurut prakarsa sendiri berdasarkan aspirasi masyarakat dalam sistem Negara Kesatuan Republik Indonesia. ${ }^{19}$

Otonomi daerah dalam aspek desentralisasi dengan tujuan ekonomi maupun politik ${ }^{20}$ menjadi wacana dan praktik kenegaraan yang pada 2 (dua) dekade terakhir menjadi topik sangat penting dalam perdebatan teori dan pengembangan kebijakan. ${ }^{21}$ Berdasarkan kajian Bank Dunia, desentralisasi sebagai bagian dari otonomi daerah merupakan peralihan kekuasaan politik, fiskal, dan administratif dari pemerintah pusat kepada pemerintah daerah. Namun, implikasi utama dari transfer kekuasaan tersebut pada akhirnya bermanfaat bagi masyarakat lokal karena mereka dilibatkan dalam proses pengambilan keputusan pembangunan. ${ }^{22}$ Pertumbuhan daerah yang lebih cepat dan efisiensi dalam memenuhi kebutuhan masyarakatlah yang menjadi hal terpenting dari sebuah desentralisasi. ${ }^{23}$ Politik hukum tersebut yang menjadi urgensi dari pengaturan otonomi daerah dalam UUD NRI 1945 dan Undang-Undang Nomor 32 Tahun 2004. Politik hukum UUD NRI 1945 tidak hanya berupaya menyeragamkan daerah di Indonesia ke dalam suatu kerangka yang sama. Pengaturan dalam Pasal 18B memberikan peluang bagi kekhususan dan keistimewaan satuan-satuan pemerintahan daerah. Pasal 18B memberikan kesempatan dilaksanakan otonomi asimetri.

Pembahasan mengenai otonomi asimetri pertama kali dibahas oleh Charles Tarlton (1965) dari University of California. Menurut ilmuwan ini, pembeda utama antara desentralisasi biasa (simetri) dengan otonomi asimetri terletak pada tingkat kesesuaian (conformity) dan keumuman (commonality) dalam hubungan suatu level pemerintahan (negara bagian/daerah) dengan sistem politik dengan sistem pemerintah pusat maupun antar negara bagian/daerah. ${ }^{24}$ Pola simetris ditandai oleh "the level of conformity and commonality in the relations of each separate political unit of the system to both the

8 Lihat Pasal 1 Angka 5 Undang-Undang Nomor 32 Tahun 2004.

19 Lihat Pasal 1 Angka 6 Undang-Undang Nomor 32 Tahun 2004.

20 Lihat Thahya Supriatna dalam Utang Rosidin, Otonomi Daerah Desentralisasi, (Bandung: CV Pustaka Setia Bandung, 2010), hlm. 88.

21 Lihat World Bank, Decentralization Home Page di http://www1.worldbank.org/wbiep/ decentralization/about.html (diakses 15 Agustus 2012).

22 Lihat World Bank, How We Work with Civil Society, online document available at: http://lnweb18.worldbank.org/ ECA/eca.nsf/Initiatives/A98CDE16184FEDFC85256BD6004F486F?OpenDcument (diakses 30 Januari 2014).

23 Lihat Iwan J Azis, "Institutional Constraints And Multiple Equilibria In Decentralization", Jurnal RURDS Cornell University, (Vol. 20, Nomor 1, March 2008): 13.

24 Robert Endi Jawang, "Kritik Terhadap Desentralisasi Asimetri di Indonesia”, Jurnal Analisis CSIS, Center For Strategic And International Studies, (Vol. 40, Nomor 2, Juni 2011): 162. 
system as a whole and to the other component units", di sisi lain pola asimetris merupakan satu atau lebih unit politik atau pemerintah lokal "possessed of varying degrees of autonomy and power". ${ }^{25}$

Kerangka pemikiran Tarlton tersebut diadopsi dan diperbarui oleh John McGarry (2007) dari Queen's University. McGarry mengembangkan otonomi asimetri Tarlton tidak hanya terkait substansi asimetri tetapi juga bentuk dasar pengaturan hukumnya. Menurut McGarry, model asimetri akan terjadi apabila otonomi semua unit pemerintahan substansional dijamin Konstitusi dan terdapat sekurang-kurangnya satu unit lokal yang menikmati level otonomi yang berbeda (umumnya otonomi yang lebih luas). ${ }^{26}$

Di Indonesia, konsep otonomi asimetri McGarry secara teori dan praktik telah diterapkan. Pertama, negara telah mengatur perlakuan khusus atau istimewa terhadap satuan-satuan pemerintahan daerah yang secara konstitusional diatur dalam Pasal 18B UUD NRI 1945. Kedua, Indonesia telah memiliki 4 (empat) daerah di level pemerintahan provinsi yang menikmati otonomi asimetri, yaitu DKI Jakarta, Nanggroe Aceh Darusalam, Papua dan Papua Barat, dan Daerah Istimewa Yogyakarta. Ketiga daerah tersebut memiliki dasar pembentukan kekhususan/keistimewaan dengan undang-undang.
Secara teoritis, penyelenggaraan otonomi daerah pada hakikatnya menekankan pentingnya prinisp-prinsip demokrasi, kemandirian daerah, peningkatan peran masyarakat, pemerataan keadilan dan kesejahteraan dengan memperhitungkan bebagai aspek yang berkenaan dengan potensi daerah. ${ }^{27}$ Keadilan dalam konteks ini tercapai apabila dilakukan pencarian hakikat umum di dalam konsep-konsep yang ada selama ini mengenai apa yang adil dan tidak adil. ${ }^{28} \mathrm{Hal}$ ini sejalan dengan pemikiran kebangkitan bangsa dalam mencari pola keadilan setelah runtuhnya rezim otoritarianisme dan lahirnya fase otonomi daerah yang merasa telah terjadi ketidakadilan antara perlakuan daerah-daerah di Indonesia pada masa Orde Baru yang sentralistik. ${ }^{29}$ Model otonomi asimetri ini terbagi atas beberapa model, yaitu sebagai berikut: ${ }^{30}$

a. Model Otonomi Asimetris Penuh.

Setiap daerah diperlakukan secara berbedabeda karena mengasumsikan adanya pluralisme yang sangat ekstrem yang harus direspons pemerintah nasional. Level daerah yang didefinisikan sebagai asimetris juga tidak sama, sangat ditentukan entitas daerah seperti apa asimetris diberikan. Model ini memang bisa menjawab keragaman daerah, namun juga berpotensi menghasilkan anarkisme dalam hubungan pusat daerah. Prasyarat pengembangan model ini adalah 
kapasitas nasional yang sangat kuat dalam supervisi desentralisasi.

b. Model Asimetris Berbasis Kategori Kemajuan Sosial Ekonomi.

Kawasan-kawasan yang ada dijustifikasi secara berbeda dengan mempertimbangkan beberapa ukuran, misalnya ukuranukuran yang bersifat teknokratis, dengan memperhatikan aspek-aspek sosial dan ekonomi tertentu. Secara lebih umum, pendefinisian model ini bisa berangkat dari ukuran-ukuran pembangunan dengan membedakanantarakawasanyangtertinggal.

Dalam konteks Indonesia, perbedaan perlakuan atas kawasan perbatasan dan kepulauan misalnya, akan bisa menjadi pertimbangan atas bentuk asmetris yang akan dikembangkan. Contoh lain dalam kategori ini adalah derajat kemajuan sosialekonomi, yang menghasilkan kategori rural-urban. Pengembangan model ini akan menjadi jawaban untuk pengembangan kawasan dengan kemajuan ekonomi dan persoalan urbanisasi yang sangat advanced.

c. Model Kombinasian Antara Otonomi Khusus dan Otonomi Reguler

Model yang sangat jamak ditemui adalah otonomi khusus sebagai solusi untuk menyelesaikan ketegangan antara pemerintah nasional dengan sub nasional yang mengarah ke gerakan-gerakan pemisahan diri (secession) atau dikarenakan karakter daerah yang sangat spesifik. Model ini selanjutnya menghasilkan bentuk desentralisasi yg bersifat reguler bagi mayoritas daerah, dan bentuk khusus untuk daerah-daerah tertentu. Dalam desain desentralisasi dan otonomi Indonesia, pilihan terhadap model ini sudah dilakukan dalam kasus 4 daerah khusus/istimewa.
Berdasarkan pendapat Pratikno dan teori yang dikemukakan oleh McGarry tersebut di atas maka dapat dianalisis bahwa Pulau Batam sebagaidaerah yang secarahistoris telah memiliki kekhususan dalam pengelolaannya memenuhi kriteria sebagai daerah otonomi asimetri. Pulau Batam yang ditetapkan sebagai daerah industri, daerah industri yang memiliki status entrepot partikelir, daerah dengan wilayah usaha Bonded Warehouse, daerah industri yang dikelola oleh Otorita Batam, dan terakhir sebagai Kawasan Perdagangan Bebas dan Pelabuhan Bebas yang dikelola oleh Badan Pengusahaan, menjadikan Pulau Batam sebagai level pemerintahan yang khusus (asimetri). Bahkan sebelum lahirnya Undang-Undang Nomor 53 Tahun 1999 yang membentuk Pemkot Batam dengan segala peraturan perundang-undangan mengenai otonomi daerah, kekhususan Pulau Batam yang dikelola oleh otoritas khusus yang terbentuk terlebih dahulu sebelum terbentuknya Pemkot Batam.

\section{Alasan Kekhususan Batam}

Sebagai bagian dari pemerintahan daerah sekaligus sebagai daerah industri, serta kawasan perdagangan bebas dan pelabuhan bebas Batam, menempatkan Batam sebagai objek tunggal yang dikelola oleh 2 (dua) otoritas yang berbeda, yaitu Badan Pengusahaan dan Pemkot Batam. Padahal, Batam merupakan suatu wilayah strategis yang sejak lama didesain untuk menjadi daerah industri, serta kawasan perdagangan bebas dan pelabuhan bebas sebagaimana Singapura. Kekhususan Batam melalui pembentukan otonomi khusus Batam menjadi hal yang urgen agar Batam dapat berkembang jauh dibandingkan kondisi saat ini. Tentunya perkembangan Batam akan sangat mempengaruhi perekonomian bangsa 
Indonesia secara umum. Terdapat beberapa alasan alasan kekhususan antara lain alasan Filosofis, Kesejarahan-Politis, Yuridis, serta Teoritis-Akademik yang akan diuraikan sebagai berikut:

\section{a. Alasan Filosofis}

Hakikat otonomi daerah adalah desentralisasi atau proses pendemokrasian pemerintahan dengan keterlibatan langsung warga masyarakat sehingga meskipun menggunakan pendekatan lembaga perwakilan. Hal demikian membuat pemerintah pusat harus memperhatikan mengenai suasana lingkungan suatu pemerintahan daerah yang berada dalam sistem negara kesatuan Republik Indonesia. Sebagai negara kesatuan yang memiliki dinamika sosial, budaya, ekonomi, dan politik di tingkat lokal menjadi suatu pertimbangan penting dalam rangka penyelenggaraan pemerintahan di tataran pemerintahan lokal. Perkembangan masyarakat yang dinamis, khususnya di daerah-daerah tertentu yang berbeda dengan perkembangan masyarakat di daerah lain harus dipertimbangkan dalam rangka pengambilan kebijakan dalam penyelenggaraan pemerintahan daerah. Bentuk kebijakan yang afirmatif merupakan hal yang pasti akan memberikan kesejahteraan masyarakat daerah namun tetap dalam konteks negara kesatuan Republik Indonesia. Keberhasilan di suatu daerah akan menciptakan keberhasilan pula di daerah sekitarnya, misalnya Pulau Bintan dan Pulau Karimun.

Orientasi daerah-daerah yang menjadi pusat industri dan perekonomian akan sangat meningkat dalam kaitannya dengan globalisasi. Daerah-daerah yang menjadi basis industri seperti Pulau Batam yang bahkan secara geografis berada pada jalur perdagangan internasional, melumpuhkan garis-garis teritotorial secara mutlak. Dunia menjadi saling terhubung dan terbuka dan perekonomiannya semakin tergantung satu dengan lainnya. Filosofi globalisasi di Pulau Batam yang ditandai dengan pembentukan Batam sebagai kawasan perdagangan bebas dan pelabuhan bebas menjadi suatu kekhususan bagi Pulau Batam dibandingkan dengan daerah lainnya.

Pola hubungan tersebut dilaksanakan secara umum maupun secara khusus. Pola hubungan yang khusus dilandasi oleh adanya ketidakpuasan daerah akan kebijakan pemerintah pusat. $^{31}$ Pola hubungan khusus tersebut dapat saja dimaknai sebagai bentuk adanya diskriminasi antar daerah. Namun, secara internasional pengkhususan suatu daerah tertentu dalam suatu negara merupakan hal yang biasa dalam konteks negara kesatuan ketika di daerah tersebut memiliki kekhasan tertentu.

Pola hubungan antara pemerintah pusat dengan pemerintah daerah tersebut dapat mengalami gradasi yang disebabkan oleh 3 (tiga) aspek, yaitu (1) pola tata kelola internal, (2) besar kewenangan, (3) besar sumber keuangan. ${ }^{32} \mathrm{Hal}$ inilah yang dalam konteks kekhususan Batam dapat dijadikan alat ukur dalam menganalisis hubungan pusat dan daerah. Di Pulau Batam secara internal memiliki suatu tata kelola yang berbeda dengan daerah lain.

31 Irfan Ridwan Maksun, Spektrum Otonomi Kekhususan, Kompas 28 Januari 2014.

32 Irfan Ridwan Maksun, ibid. 


\section{a. Alasan Kesejarahan-Politis}

Dalam lintasan sejarah perkembangan Pulau Batam dan politik hukum pengelolaan Pulau Batam telah dimulai sejak tahun 1970 dengan diterbitkannya Keputusan Presiden Nomor 65 Tahun 1970 tentang Pelaksanaan Proyek Pembangunan Pulau Batam. Pada saat itu, Pulau Batam ditetapkan sebagai basis logistik dan operasional bagi usaha-usaha yang berhubungan dengan eksplorasi dan eksploitasi minyak dan gas bumi yang dilaksanakan oleh Perusahaan Negara Pertambangan Minyak dan Gas Bumi Nasional (PN Pertamina). Pulau Batam pada saat itu telah menjadi daerah industri yang sejak itu pula Pulau Batam mulai terkoneksi dengan wilayah-wilayah lain di sekitar Pulau Batam baik dalam negeri maupun luar negeri. Pembangunan Pulau Batam tersebut merupakan konsekuensi dari mulai adanya koneksi antara negara-negara yang saling terhubung dan saling mempengaruhi dalam bidang industrialisasi. ${ }^{3.3}$

Sejaktahun 1970-an Batam sudah diposisikan sebagai daerah industri khususnya industri yang terkait dengan bidang usaha Pertamina. Hal ini didasari oleh letak strategis Pulau Batam yaitu terletak Batam yang terletak di jalur lalu lintas Asia Barat-Asia Timur yang berada di lintas perdagangan internasional, sehingga potensi strategis tersebut dapat dimanfaatkan oleh Pertamina dalam usaha minyak dan gas bumi.

Pada Tahun 1971, pengembangan Pulau Batam diperluas tidak hanya pada pembangunan industri eksplorasi dan eksploitasi minyak dan gas bumi dengan penetapan Pulau Batam sebagai daerah Industri berdasarkan Keputusan Presiden Nomor 74 Tahun 1971 tentang Pengembangan Pembangunan Pulau Batam. Berdasarkan Keputusan Presiden Nomor 74 Tahun 1971 tersebut, sebagian dari Pulau Batam ditetapkan sebagai daerah industri yang diberi status sebagai entrepot partikelir ${ }^{34}$ berdasarkan ketentuan dalam Reglemen A dari Ordonansi Bea. ${ }^{35}$

Dalam perkembangannya, sebagai upaya untuk meningkatkan dan memperlancar pengembangan daerah industri Pulau Batam maka Keputusan Presiden Nomor 74 Tahun 1971 disempurnakan dengan diterbitkan Keputusan Presiden Nomor 41 Tahun 1973 tentang Daerah Industri Batam. Keputusan Presiden Nomor 41 Tahun 1973 mengubah kelembagaan tunggal Badan Pimpinan menjadi kelembagaan yang terdiri atas: Badan Pembina Daerah Industri Pulau Batam, Otorita Pengembangan Daerah Industri Pulau Batam, dan Perusahaan Perseroan Pengusahaan Daerah Industri Pulau Batam.

Hal penting dalam Keppres Nomor 41 Tahun 1973 yaitu mengenai pengaturan peruntukan dan penggunaan tanah di daerah industri Pulau Batam, yaitu peruntukan dan penggunaan tanah di daerah industri Pulau Batam untuk keperluan bangunan-bangunan, usaha-usaha, dan fasilitas-fasilitas lainnya yang bersangkutan dengan pelaksanaan pembangunan Pulau

\footnotetext{
33 N. A. Phelps, "Archetype for an Archipelago? Batam as Anti-model and Model of Industrialization in Reformasi Indonesia", School of Geography, University of Southampton, UK, Progress in Development Studies July (2004, Vol. 4 Nomor 3): 206-229.

34 Entrepot partikelir adalah ruangan-ruangan yang berkenaan dengan letak dan susunan yang memenuhi syaratsyarat yang ditetapkannya sebagai entrepot partikelir untuk menimbun (menyimpan) barang yang impor.

35 Lihat Keputusan Presiden Nomor 74 Tahun 1971 tentang Pengembangan Pembangunan Pulau Batam.
} 
Batam dengan didasarkan atas suatu rencana tata-guna tanah dalam rangka pengembangan Pulau Batam menjadi daerah industri. Melalui norma tersebut, Otorita Batam menjadi penguasa atas lahan di Pulau Batam sehingga memiliki kewenangan besar dan tunggal untuk mengadakan peruntukan dan penggunaan tanah di Pulau Batam. Lebih lanjut, hal-hal yang bersangkutan dengan pengurusan tanah di dalam wilayah daerah industri Pulau Batam diatur lebih lanjut oleh Menteri Dalam Negeri ${ }^{36}$ sesuai dengan peraturan perundang-undangan yang berlaku di bidang agraria.

Sementara itu sebagai daerah industri, Pulau Batam statusnya diperkuat dengan menetapkan seluruh Pulau Batam sebagai wilayah usaha Bonded Warehouse melalui Keputusan Presiden Nomor 41 Tahun 1978 tentang Penetapan Seluruh Pulau Batam Sebagai Wilayah Usaha Bonded Warehouse. Berdasarkan Keputusan Presiden Nomor 41 Tahun 1978 status Pulau Batam diperluas tidak hanya menjadi daerah industri tetapi juga wilayah pabean atas barang impor, ekspor, dan re-ekspor ke dan dari Pulau Batam mendapatkan kebebasan bea, cukai, atau pungutan Negara lainnya.

Penetapan Pulau Batam sebagai daerah industri mengalami perkembangan pada tahun 2000-an dengan penerbitan Peraturan Pemerintah Pengganti Undang-Undang Nomor 1 Tahun 2000 tentang Kawasan Perdagangan Bebas dan Pelabuhan Bebas. Peraturan Pemerintah Pengganti Undang-Undang ini kemudian ditetapkan menjadi Undang-Undang Nomor 36 Tahun 2000 tentang Penetapan Peraturan Pemerintah Pengganti Undang-
Undang Nomor 1 Tahun 2000 tentang Kawasan Perdagangan Bebas dan Pelabuhan Bebas Menjadi Undang-Undang.

Pembentukan Kawasan Perdagangan Bebas dan Pelabuhan Bebas berdasarkan Undang-Undang Nomor 36 Tahun 2000 dengan Peraturan Pemerintah Nomor 46 Tahun 2007 tentang Kawasan Perdagangan Bebas dan Pelabuhan Bebas Batam ditetapkan Batam sebagai kawasan perdagangan bebas dan pelabuhan bebas. Berdasarkan Peraturan Pemerintah Nomor 46 Tahun 2007, dibentuk juga Badan Pengusahaan Kawasan Perdagangan Bebas dan Pelabuhan Bebas Batam. Sebelum Badan Pengusahaan belum terbentuk maka tugas dan wewenangnya dilaksanakan secara bersama antara Pemerintah Kota Batam (selanjutnya disebut Pemkot Batam) dengan Badan Pengusahaan sesuai dengan tugas pokok dan fungsi masing-masing. Adapun tugas dan wewenang dari Badan Pengusahaan adalah melaksanakan pengelolaan, pengelolaan, dan pembangunan kawasan perdagangan bebas dan pelabuhan bebas sesuai dengan fungsi kawasan perdagangan bebas dan pelabuhan bebas termasuk untuk membuat ketentuanketentuan supaya tidak bertentangan dengan Peraturan Pemerintah Nomor 46 Tahun 2007 dan peraturan perundang-undangan lainnya. Berbagai pengaturan yang menjadi politik hukum pemerintah dari masa ke masa menjadi bukti bahwa sejak tahun 1970-an Pulau Batam diperlakukan khusus sebagai oleh pemerintah pusat. Faktor kesejarahan-politis inilah yang tidak dapat dipisahkan dari alasan kekhususan Batam.

Sebagai pengaturan lebih lanjut mengenai hal tersebut diterbitkanlah Keputusan Menteri Dalam Negeri Nomor 43 Tahun 1977. 


\section{b. Alasan Yuridis}

Wacana pembentukan Pulau Batam sebagai daerah otonomi khusus secara Konstitusional didasari oleh ketentuan Pasal 18B ayat (1) UUD NRI 1945 yang menyatakan bahwa negara mengakui dan menghormati satuan-satuan pemerintah daerah yang bersifat khusus atau istimewa yang diatur dengan undang-undang. Berbagai produk hukum yang mengatur tentang pemerintahan daerah di Indonesia yang menjadi landasan hukum pembentukan otonomi khusus Batam, antara lain Undang-Undang Nomor 32 Tahun 2004 serta Peraturan Pemerintah Nomor 78 Tahun 2007 tentang Tata Cara Pembentukan, Penghapusan, dan Penggabungan Daerah. Dalam Pasal 2 ayat (8) Undang-Undang Nomor 32 Tahun 2004 juga memberi ruang afirmasi bagi predikat kekhususan atau keistimewaan sejumlah daerah. Hal ini dituangkan dalam Pasal 2 ayat (8), "Negara mengakui dan menghormati satuan-satuan pemerintahan daerah yang bersifat khusus atau bersifat istimewa yang diatur dengan undang-undang."

Dalam UUD NRI 1945 dan UndangUndang Nomor 32 Tahun 2004 tidak diatur bahwa otonomi khusus hanya diberlakukan pada pemerintah provinsi, sehingga apabila kekhususan/keistimewaan hanya pada tataran pemerintah kabupaten/kota maka otonomi khusus tersebut dapat diberlakukan pada pemerintah kota/kabupaten saja. Selain, pengaturan kekhususan dalam UUD NRI 1945 dan Undang-Undang Nomor 32 Tahun 2004, untuk Pulau Batam kekhususannya pun telah pula diatur dalam Keputusan Presiden Nomor 41 Tahun 1973. Walau berdasar hukum Keputusan Presiden, politik hukum penetapan khusus Pulau Batam sebagai Daerah Industri merupakan bentuk pengakuan dan sekaligus cita-cita pemerintah saat itu agar Pulau Batam dengan kekhususannya tersebut dapat memberikan manfaat yang sebesar-besarnya bagi masyarakat.

Hingga saat ini, Keputusan Presiden tersebut terus berlaku. Terakhir diterbitkan Keputusan Presiden Nomor 25 Tahun 2000 tentang Perubahan Kelima Keputusan Presiden Nomor 41 Tahun 1973. Berdasarkan hal tersebut, disimpulkan bahwa: pertama, adanya konsistensi yuridis mengenai kekhususan Pulau Batam sebagai kawasan khusus industri bahkan diperkuat dengan penetapan Pulau Batam sebagai kawasan perdagangan bebas dan pelabuhan bebas. Kedua, pengakuan kekhususan Pulau Batam dalam penyelenggaraan memiliki perbedaan dengan daerah-daerah lain di Indonesia secara umum. Artinya eksistensi kelembagaan dengan segala tugas pokok dan fungsinya di Pulau Batam, tidak ditemukan di daerah lain sehingga memberikan penafsiran bahwa secara empiris bahwa Pulau Batam memiliki suatu perlakukan afirmatif dari pemerintah pusat.

\section{Alasan Teoritis-Akademik}

Dalam khasanah perkembangan ilmu politik dan ilmu pemerintahan, telah banyak pembahasan mengenai praktik penyelenggaraan pemerintahan baik secara umum maupun secara khusus/istimewa. Bahkan di berbagai dunia praktik penyelenggaraan pemerintah daerah yang bersifat khusus umum terjadi, baik dalam konteks negara kesatuan maupun dalam konteks negara federatif. Dalam khasanah ilmu politik dan pemerintahan, pola pengaturan yang tidak sebanding ini disebut sebagai assymetrical decentralization, asymetrical devolution atau assymetrical federalis, atau 
secara umum assymetrical intergovernmental arrangements. ${ }^{37}$ Secara prinsipil, berbagai bentuk penyebaran kekuasaan yang bercorak asimetris di atas merupakan salah satu instrumen kebijakan yang dimaksudkan untuk mengatasi dua hal fundamental yang dihadapi suatu negara, yakni persoalan bercorak politik, termasuk yang bersumber pada keunikan dan perbedaan budaya; dan persoalan yang bersorak teknokratik-manajerial, yakni keterbatasan kapasitas suatu daerah atau suatu wilayah dalam menjalankan fungsi dasar pemerintahan. ${ }^{38}$

Pengaturan asimetris yang terkait dengan politik ditempuh sebagai strategi kebijakan untuk mempertahankan basic boundaries unit politik suatu negara dan atau sebagai aspresiasi atas keunikan budaya tertentu. Dengan tingkat keberhasilan yang berbedabeda, representasi minoritas pada level subnasional serta pemberian status keistimewaan/ khusus bagi satu daerah atau kawasan daerah dapat mendorong kelompok/daerah yang menuntut status keistimewaan/kekhususan, meniadakan/meminimalkan kekerasan dan mempertahankan keutuhan wilayah. Konstitusi Spanyol tahun 1978 setelah jatuhnya Franco misalnya, menetapkan adanya "historical rights" serta memberikan otonomi khusus dan dipercepat pada beberapa daerah, diantaranya Castile-Leon, Catalonia, Valencia. ${ }^{39}$

\section{Substansi Kekhususan Batam}

a. Bidang Politik dan Pemerintahan

Substansi dari kekhususan Batam
terletak pada kekhususan Batam dalam

penyelenggaraan pemerintahan daerah. Dalam posisi khusus sebagai daerah industri, pelabuhan dan perdagangan bebas, Batam mempunyai fungsi sebagai lokomotif pertumbuhan dan perkembangan industri, perdagangan, dan pelabuhan bebas. Sebagai konsekuensinya Batam memiliki tugas dan wewenang melakukan pengelolaan dan pengembangan kawasan perdagangan bebas dan pelabuhan bebas ini dalam bingkai Negara Kesatuan Republik Indonesia. Dengan didasari hal tersebut maka Batam harus memiliki bentuk dan susunan pemerintahan yang berbeda dengan provinsi lainnya di Indonesia. Hal ini didasarkan pada dua pertimbangan pokok: pertama, kekhususan yang dimiliki Batam membutuhkan adanya kelembagaan yang dapat mengelolanya dengan sebaik-baiknya agar dapat mencapai tujuan kekhususan itu sendiri; kedua, Batam, sebagaimana diindikasikan pada bagian sebelumnya, telah memiliki 2 (dua) kelembagaan pemerintahan sehingga menjadi tidak efektif untuk jangka waktu yang sangat lama. Substansi kekhususan dalam bidang ini perlu direvitalisasi kelembagaannya yang telah ada guna berjalannya kegiatan pemerintahan daerah di Pulau Batam. Perbedaan pokok dalam aspek kelembagaan Batam dengan daerah lainnya, yaitu adanya 2 (dua) otoritas yang memiliki kewenangan yang saling berbenturan dalam penyelenggaraan Pulau Batam, yaitu Pemerintah Kota Batam dan Badan Pengusahaan Batam. Revitalisasi atas kelembagaan tersebut dilakukan dengan melakukan reorganisasi baru di Batam dengan membentuk Kota 
Batam menjadi Provinsi baru yang memiliki kekhususan dengan menjadi gubernur sebagai kepala daerah sekaligus sebagai Kepala Badan Pengusahaan.

Dalam ranah politik, kekhususan Batam terletak pada sumber dan proses rekruitmen gubernur dan kedudukan Gubenur Batam ${ }^{40}$ sekaligus sebagai Kepala Badan Pengusahaan Batam. Rekruitmen Gubernur Batam/Kepala Pengusahaan Batam dapat dilakukan melalui skema Gubernur Batam/Kepala Pengusahaan Batam dipilih oleh DPRD. Skema ini juga khusus, artinya tidak mengikuti mekanisme pemilihan gubernur yang diatur dalam UndangUndang Nomor 32 Tahun 2004 yang mengatur gubenur dipilih langsung oleh rakyat. ${ }^{41}$ Melalui pembentukan provinsi otonomi khusus Batam dengan undang-undang yang baru maka Pemkot Batam dan Badan Pengusahaan Batam saat ini dibubarkan dan berubah menjadi Pemerintah Provinsi Otonomi Khusus Batam yang dipimpin oleh gubenur merangkap sebagai Kepala Badan Pengusahaan Batam.

\section{b. Struktur Pembentukan dan Sistem Pemerintahan Provinsi Otonomi Khusus Batam}

Terkait struktur pembentukan dan sistem Pemerintah Provinsi Otonomi Khusus Batam, terdapat beberapa hal yang menjadi kekhususan Batam. Pertama, dalam kerangka pembentukan daerah otonomi baru yang berupa pemerintah provinsi untuk Batam yang merupakan lex specialis dari ketentuan yang diatur dalam Undang-Undang Nomor 32 Tahun 2004, sehingga syarat-syarat administrasi, teknis, dan fisik kewilayahan dapat dikecualikan dari syarat-syarat yang diatur dalam UndangUndang Nomor 32 Tahun 2004. Misalnya syarat fisik kewilayahan yang meliputi paling sedikit 5 (lima) kabupaten/kota dalam pembentukan daerah otonomi baru yang berupa Provinsi Pulau Batam tidak mengikuti syarat paling sedikit 5 (lima) kabupaten/kota tersebut. Hal tersebut dimungkinkan sebagaimana dimaksud dalam Pasal 18B UUD NRI 1945.

Kedua, selain penerapan asas lex specialis dalam pembentukan daerah otonomi baru yang berupa pemerintah provinsi untuk Batam, kerangka sistem pemerintahan di Batam pun merupakan lex specialis dari ketentuan yang diatur dalam Undang-Undang Nomor 32 Tahun 2004. Ketentuan mengenai sistem pemerintahan sebagaimana diatur dalam Undang-Undang Nomor 32 Tahun 2004, misalnya mengenai ketentuan bahwa dalam suatu pemerintah provinsi harus terdapat DPRD Provinsi dan di tiap kabupaten/kota di wilayah provinsi harus terdapat DPRD Kabupaten/Kota, maka sistem pemerintahan provinsi untuk Batam kelembagaan DPRD hanya terdapat di tingkat provinsi, sedangkan di tingkat kabupaten/kota tidak perlu dibentuk DPRD Kabupaten/Kota, seperti Pemerintah Daerah Khusus Ibukota

40 Kedudukan gubernur terkait dengan kekuasaan kepala daearah sebagai lembaga eksekutif yang memegang kekuasaan dalam bentuk berbagai fungsi dan wewenang yang berhubungan dengan bidang pemerintahan daerah (Lihat Sayuti una, Pergeseran Kekuasaan Pemerintahan Daerah Menurut Konstitusi Indonesia, (Yogyakarta: UII Press, 2004), hlm. 107.

41 Pemilihan langsung oleh rakyat terkait dengan kedaulatan rakyat dengan sistem perwakilan atau demokrasi biasa juga disebut sistem demokrasi perwakilan atau demokrasi tidak langsung. Di dalam praktik yang menjalankan kedaulatan rakyat adalah wakil-wakil rakyat yang duduk di lembaga perwakilan rakyat. (Lihat Jimly Asshiddiqie, Pengantar Ilmu Hukum Tata Negara, (Jakarta: Rajagrafindo, 2013), hlm. , (Jakarta: Rajagrafindo, 2013), hlm. 328 
Jakarta yang menjadikan Kabupaten/kota di wilayah sebagai daerah administratif.

Ketiga, Gubernur Provinsi Otonomi Khusus Batam dalam penyelenggaraan pemerintahan bertindak sebagai kepala wilayah, Kepala daerah otonomi khusus Batam, dan Kepala Badan Pengusahaan Batam. Peran dan fungsi Gubernur sesuai yang diatur dalam UndangUndang tentang Pembentukan Provinsi Otonomi Khusus Batam. Keempat, DPRD provinsi daerah khusus Batam merupakan unsur legislatif dalam penyelenggaraan pemerintahan yang peran dan fungsi DPRD diatur sesuai yang diatur dalam Undang-Undang tentang Pembentukan Provinsi Otonomi Khusus Batam. Kelima, Pemerintah Kabupaten/Kota di Wilayah Pemerintah Provinsi Otonomi Khusus Batam berbentuk kabupatan/ kota administratif yang jabatan walikotanya ditunjuk oleh gubenur. Hal yang dilakukan pula di DKI Jakarta.

\section{c. Pengisian Jabatan}

Proses rekruitmen dan pengisian jabatan unsur penyelenggara pemerintahan Gubernur dilaksanakan secara khusus. Gubernur Pemerintah Otonomi Khusus Batam/Kepala Badan Pengusahaan. Pengisian jabatan Gubernur Provinsi Daerah Khusus Batam dilakukan melalui mekanisme dipilih oleh DPRD Khusus yang dipilih melalui mekanisme pemilihan langsung sesuai dengan prinsip demokrasi sebagaimana diatur dalam peraturan perundang-undangan. Selanjutnya Walikota akan ditunjuk dan ditetapkan oleh Gubenur Batam.

\section{d. Kedudukan dan Kewenangan}

Gubernur Pemerintah Provinsi Khusus Batam/Kepala Badan Pengusahaan memiliki kedudukan sebagai (a) kepala wilayah dengan kewenangan sebagaimana diatur dalam peraturan perundang-undangan; (b) Kepala daerah dengan kewenangan sebagaimana diatur dalam peraturan perundang-undangan; dan (c) Kepala Badan Pengusahaan Batam dengan kewenangan yang diatur dalam peraturan perundang-undangan. DPRD berkedudukan sebagai representasi rakyat dengan kewenangan sebagaimana diatur dalam peraturan perundang-undangan. Sedangkan Walikota-Walikota di Pulau Batam. WalikotaWalikota di Pulau Batam bekedudukan di bawah gubenur dan bertanggung jawab langsung kepada gubenur.

\section{e. Hubungan Antar Lembaga}

Kedudukan dan kewenangan masingmasing lembaga dalam struktur pemerintah daerah Provinsi Daerah Khusus Batam tersebut di atas melahirkan hubungan kewenangan. Pertama, hubungan pemerintah pusat dan pemerintah khusus Batam. Wakil pemerintah pusat di pemerintah provinsi Batam adalah Gubernur dalam posisinya sebagai Kepala Wilayah Administratif, merujuk pada Integrated Prefectoral System sebagaimana diatur dalam peraturan perundang-undangan. Dalam kedudukan demikian, terdapat hubungan kewenangan yang besifat hierarkis antara Presiden dengan Gubernur. Presiden berwenang memberikan instruksi kepada Gubernur, termasukuntukmenjalankanfungsipengawasan terhadap institusi-institusi pemerintahan yang ada di daerah, serta menjalankan kewajibankewajiban lainnya yang diatur dalam peraturan perundang-undangan. Kedua, hubungan Pemerintah Provinsi Batam dan Pemerintah Provinsi lainnya. Pada prinsipnya di Provinsi Khusus Batam hubungan antara Pemerintah Provinsi Batam dengan pemerintah provinsi 
lainnya adalah sebagaimana diatur dalam Undang-undang tentang pemerintah daerah, kecuali yang menyangkut urusan-urusan yang dinyatakan sebagai substansi khusus Provinsi Batam.

Secara skematik, hubungan kewenangan di antara lembaga-lembaga di tingkat pemerintahan Batam adalah sebagai berikut:

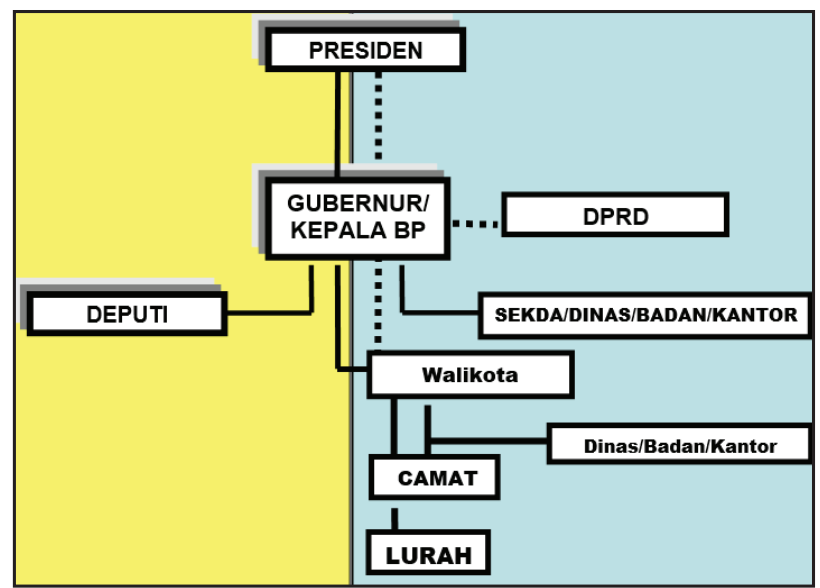

Gambar 1. Skema Pola Organisasi Pemerintah Daerah Provinsi Otonomi Khusus Batam

\section{f. Bidang Perekonomian, Pertanahan, dan Penataan Ruang}

Penyelenggaraan pemerintah daerah khusus Batam dilakukan dengan pengaturan terhadap kewenangan perekonomian, pertanahan, dan penataan ruang. Kewenangan khusus dalam ketiga urusan ini diwujudkan melalui kewenangan penuh dalam menetapkan kebijakan-kebijakan dan dalam merumuskan Peraturan Daerah Khusus tentang ketiga urusan pemerintahan itu.

Di bidang perekonomian, Pemerintah Daerah Khusus Batam memiliki kewenangan untuk mengatur secara luas bidang-bidang perekonomian, misalnya mengenai pabean, cukai, pajak daerah dan retribusi daerah. Bidang-bidang tersebut tidak terikat dengan ketentuan-ketentuan yang berlaku secara nasional. Pengaturan yang saat itu masih bersifat top-down menjadi persoalan lain ketika dinamika perkambangan Batam tidak dapat direspon secara cepat, sehingga pengaturan sendiri oleh Pemerintah Daerah Khusus Batam mengenai bidang-bidang perekonomian, akan membuat Batam akan secara cepat merespon perkembangan perekonomian global.

Di bidang pertanahan, di Batam melalui Keputusan Presiden Nomor 41 Tahun 1973 telah memiliki kekhususan pengelolaan pertanahan dengan pemberian hak pengalolaan atas tanah di seluruh wilayah Pulau Batam kepada Badan Pengusahaan Batam. Selanjutnya, dalam pengaturan mengenai kekhususan Batam sebagai Pemerintah Daerah Khusus Batam maka kewenangan pertanahan dalam hal ini hak pengelolaan atas tanah termasuk tanah hasil reklamasi pantai, diintegrasikan menjadi kewenangan Gubenur Batam. Dengan demikian perencanaan, pelaksanaan reklamasi, dan pengelolaan hasil reklamasi dapat dilaksanakan dengan baik dan tidak terjadi tumpang tindih kewenangan. Meskipun Gubernur Batam merupakan penguasa di Batam, namun pertanggungjawaban tetap kepada Presiden sehingga tetap ada pengawasan dari pemerintah pusat. Alasan pengawasan oleh Pemerintah Pusat tersebut antara lain karena perlunya Pemerintah Pusat untuk menetapkan serta mempertahankan standard minimun dalam pemberian pelayanan kepada masyarakat oleh pemerintah daerah. ${ }^{1}$

Di bidang penataan ruang, ruang bagi Batam memiliki fungsi industri, perdagangan bebas,

1 Josef Riwu Kaho, Analisis Hubungan Pemerintah Pusat dan Daerah di Indonesia, (Yogyakarta: L Polgov Fisipol UGM, 2012), hlm. 304. 
dan pelabuhan bebas. Sebagai kawasan yang memiliki fungsi tersebut, maka penataan ruang di Pulau Batam harus berbeda pengaturannya dengan penataan ruang di daerah lainnya. Perbedaan tersebut misalnya mengenai penetapan ruang kawasan hutan di Pulau Batam yang selama ini penetapan kawasan hutan di Pulau Batam melalui Keputusan menteri Kehutanan. Melalui kekhususan Batam maka penetapan ruang baik kawasan hutan maupun bukan kawasan hutan tidak lagi tergantung dengan pola penetapan sesuai dengan ketentuan dalam Undang-Undang Nomor 26 Tahun 2007 tentang Penataan Ruang dan Undang-Undang Nomor 41 Tahun 1999 tentang Kehutanan. Dengan demikian, seluruh lahan di Pulau Batam baik di dalam maupun luar kawasan hutan menjadi hak pengelolaan atas tanah Gubernur Provinsi Otonomi Khusus Batam yang penetapan tata ruangnya dilaksanakan untuk sepenuhnya menunjang Batam sebagai daerah industri dan perdagangan bebas serta pelabuhan bebas.

\section{Penutup}

Akhirnya, gagasan pembentukan pemerintah provinsi khusus Batam menjadi salah satu gagasan yang progresif dalam menyelesaikan berbagai persoalan di Batam dan pengaruh positifnya bagi pelaksanaan AEC 2015 agar AEC 2015 memberikan manfaat yang besar bagi Batam. Berdasarkan kajian politis-kesejarahan, filosofis, yuridis, dan teoritik-adakemik, Batam telah lama berlaku khusus (asimetri) yang berbeda dengan daerah-daerah lain di Indonesia. Kekhususan Batam dilaksanakan melalui pembentukan Batam sebagai provinsi otonomi khusus dengan kewenangankewenangan eksklusif dalam bidang politik dan pemerintahan, serta pertanahan, kehutanan, tata ruang, dan perekonomian. Melalui pembentukan otonomi khusus Batam ini Gubernur Batam merupakan kepala daerah yang juga merangkap sebagai Kepala Badan Pengusahaan. Hal ini sebagai solusi benturan kewenangan antara Walikota Batam dengan Kepala Pengusahaan Batam dapat terselesaikan, sekaligus menghilangkan benturan pengaturanpengaturan terkait Batam karena dalam undangundang mengenai kekhususan Batam peraturan perundang-undangan yang saling bertentangan terkait Batam akan dicabut dan dinyatakan tidak berlaku.

Melalui pembentukan Pemerintah Provinsi Otonomi Khusus Batam, tidak hanya persoalan tumpang tindih kewenangan dan pengaturan di Batam yang terselesaikan, namun secara luas pembentukan provinsi khusus Batam menjadi suatu solusi pembangunan dan pengembangan Batam agar mampu tumbuh dan berkembang seperti Singapura serta menjadi pemerintah daerah di Indonesia yang mampu mewujudkan 1) ASEAN sebagai aliran bebas barang, bebas jasa, bebas investasi, bebas tenaga kerja terdidik, dan bebas modal; (2) ASEAN sebagai kawasan dengan daya saing tinggi; (3) ASEAN sebagai kawasan dengan pengembangan ekonomi yang merata dengan elemen pengembangan usaha kecil menengah, dan (4) ASEAN sebagai kawasan terintegrasi. Tentunya tujuan tersebut memberikan manfaat yang besar bagi kesejahteraan dan kemakmuran rakyat Indonesia.

Sebagai saran, Pemerintah atau DPR RI sebaiknya segara melakukan perencanaan mengenai penetapan kekhususan Batam yang dilakukan dengan mengkaji dan melakukan pemenuhan syarat-syarat administratif, teknis, dan fisik kewilayahan untuk menjadikan Batam sebagai pemerintah propinsi otonomi khusus 
yang keluar dari wilayah Propinsi Kepulauan Riau. Hal ini mengingat pelaksanaan AEC 2015 sudah sangat dekat. Melalui inisiatif Pemerintah atau DPR RI segara menyusun naskah akademik dan naskah rancangan Undang-Undang tentang Pembentukan Pemerintah Propinsi Otonomi Khusus untuk segera dibahas dan disetujui menjadi daerah otonomi baru yaitu Pemerintah Propinsi Otonomi Khusus.

Perencanaan tersebut dilakukan mulai dari pembahasan tingkat internal Kementerian Dalam Negeri dengan melibatkan para ahli di bidang pemerintahan daerah mengenai gagasan pembentukan provinsi otonomi khusus Batam. Pembahasan di tingkatan interen Kementerian Dalam Negeri menghasilkan produk naskah akademik dan naskah RUU tentang Pembentukan Provinsi Otonomi Khusus Batam. Setelah pembahasan di tingkat interen Kementerian Dalam Negeri tuntas, maka dilanjutkan dengan pembahasan antar kementerian, pengharmonisasian di Kementerian Hukum dan HAM, dan penyampaikan kepada Presiden/DPR untuk disampaikan kepada DPR/Presiden.

\section{DAFTAR PUSTAKA}

\section{Buku}

Alexander and Glower, R, W, International Investment, (London: Penguin Books, 1972).

Assidiqie, Jimly, Gagasan Kedaulatan Rakyat dalam Konstitusi dan Pelaksanaannya di Indonesia, (Jakarta: PT Ichtiar Baru van Hoeve, 1994).

Assidiqie, Jimly, Pengantar Ilmu Hukum Tata Negara, (Jakarta: raja grafindo, 2013).

Harris, Myra, Legal Research, (Jersey: PrenticeHallInc New, 1997).

I Gde Pantja Astawa dan Suprin Na'a, Ilmu Negara dan Teori Negara, (Bandung: Refika Aditama, 2009).

J. Kartini, Soedjendro, Perjanjian Peralihan Hak Atas Tanah yang Berpotensi Konflik, (Jakarta: Kanisius, 2001).
Kaloh, J., Mencari Bentuk Otonomi Daerah, (Bandung: Rineka Cipta, 2002).

Kartosapoetra, Masalah Pertanahan di Indonesia. Rineka Suatu Sistem, (Bandung: RinekaCipta, Cet. II, 1992).

Kusuma, R.M, A.B, Lahirnya Undang-Undang Dasar 1945, (Jakarta: Badan Penerbit Fakultas Hukum Universitas Indonesia, 2004).

Leback, Karen, Teori-teori Keadilan, terjemahan, (Bandung: Nusa Media, 2012).

Mertokusumo, Sudikno, Mengenal Hukum: Suatu Pengantar, (Yogyakarta: Penerbit Liberty, 1999).

Riwu kaho, Josep, Analisis Hubungan Pemerintah Pusat dan Daerah di Indonesia, (Yogyakarta: Polgov Fisipol UGM, 2012).

Rosidin, Itang, Otonomi Daerah dan Desentralisasi, (Bandung: Pustaka Setia, 2010).

Sarundajang, S.J., Arus Balik Kekuasaan Pusat ke Daerah, (Jakarta: Pustka Sinar Harapan, 2002).

Soehino, Bunga Rampai Hukum Tata Negara, (Yogyakarta: Fakultas Ekonomika dan Bisnis UGM, 2010).

Sujamto, et.al., Proses Pembuatan Undang-Undang Nomor 5 tahun 1974 tentang Pokok-pokok Pemerintahan di Daerah (ed. Revisi), (Jakarta: Bina Aksara, 1985).

Sujamto, et.al., Undang-Undang Nomor 5 tahun 1974 tentang Pokok-Pokok Pemerintahan di Daerah dan Proses Kelahirannya, (Jakarta: Biro Hukum dan Humas Sekjen Depdagri, 1977).

Syarifusin, Ateng, Titik Berat Otonomi Daerah Pada Daerah Tingkat II dan Perkembangannya, (Bandung: CV Masdar Maju, 1981).

Una, Sayuti, Pergeseran Kekuasaan Pemerintah Daerah Menurut Konstitusi Indonesia, (Yogyakarta: UII Press, 2004).

\section{Makalah/Artikel/Hasil penelitian}

Atmadja, I Gede, "Penafsiran Konstitusi Dalam Rangka Sosialisasi Hukum: Sisi Pelaksana UUD 1945 secara murni dan konsekuen", Pidato guru besar dalam bidang IImu Hukum Tata Negara pada Fakultas Hukum Universitas Udayana, (10 April 1996).

Brown, Archie, "Asymetrical Devolution: The Scottish Case", Political Quarterly, (Juli-September 1998, Vol. 69, Issue 3).

Deloitte Access Economic, "The Connected Archipelago: The role of the Internet in Indonesia's economic development", (Desember 2011). 
Endi Jawang, Robert, "Kritik Terhadap Desentralisasi Asimetri di Indonesia", Jurnal Analisis CSIS, Center For Strategic And International Studies, (Vol. 40, Nomor 2, Juni, 2011).

Ismail, Nurhasan, "Menempatkan realitas Pertanahan Lokal dalam Rancangan UndangUndang Keistimewaan DIY", Makalah Seminar tentang Sistem Pertanahan di DIY dalam Kerangka Keistimewaan, diselenggarakan Parwi Foundation, Yogyakarta, (26 April 2003).

J. Azis, Iwan, "Institutional Constraints and Multiple Equilibria In Decentralization", Jurnal RURDS Cornell University, (Vol. 20, Nomor 1, March 2008).

Joachim, Wehner, H-G, "Asymmetrical Devolution", Development Southern Africa, (Vol 17, Nomor 2 Juni, 2000).

Joachim, Wehner, H-G, Unsur Keistimewaan Bidang Pertanahan dan Alternatif Materi dan Muatannya, disampaikan dalam Diskusi Panel Ahli I Penyusunan Rancangan Undang-Undang Keistimewaan Yogyakarta yang diselenggarakan oleh Jurusan IImu Pemerintahan FISIPOL UGM, Yogyakarta, (11 Mei 2007), (Tidak dipublikasikan).

Kementerian Kelautan dan Perikanan, "Kelautan dan Perikanan Dalam Angka Tahun 2012", (Jakarta, 2011).

Maria Sumardjono, "Pokok-Pokok Pikiran tentang Keistimewaan Yogyakarta di Bidang Pertanahan", makalah Sarasehan: Format Keistimewaan Yogyakarta untuk Kesejahteraan Rakyat dan Kebhinekaan Republik Indonesia kerjasama UGM dengan Pengurus Daerah KAGAMA DIY, Yogyakarta, (9-10 Mei 2007), (Tidak dipublikasikan).

Meredith, Weiss, "The Basque Nationalist Movement", Paper, (1 November 2002).

Minde, Henry, Sami Land Right In Norway: A Test Case for Indigenous Peoples, International Journal on Minority and Group Rights, Netherland, (2001).

Phelps, N. A., "Archetype for an archipelago? Batam as anti-model and model of industrialization in reformasi Indonesia", School of Geography, University of Southampton, UK, Progress in Development Studies (Vol. 4, Nomor 3, July, 2004).

Pratikno, dkk, "Desentralisasi Asimetri di Indonesia: Praktek dan Proyeksi", hasil penelitian Jurusan Politik dan Pemerintahan, Fakultas IImu Sosial dan Ilmu Politik, Universitas Gadjah Mada, Yogyakarta, (2010).
Thaib, Dahlan, "Keistimewaan DIY Perspektif Hukum Tata Negara", Sarasehan: Format Keistimewaan Yogyakarta untuk Kesejahteraan Rakyat dan Kebhinekaan Republik Indonesia kerjasama UGM dengan Pengurus Daerah KAGAMA DIY, Yogyakarta, (9-10 Mei 2007), (Tidak dipublikasikan).

\section{Internet}

Decentralization Home Page di http://www1. worldbank.org/wbiep/ decentralization/about. html (diakses 30 Januari 2014).

How We Work with Civil Society, online document: http://Inweb18.worldbank.org/ECA/eca.nsf/ Initiatives/A98CDE16184FEDFC85256BD6004F 486F?OpenDcument. (diakses 30 januari 2014).

http://gulfnews.com/ (diakses 24 Januari 2014).

http://megayachts.ru/en/news/view/id/652 (diakses 2 Januari 2014).

http://plato.stanford.edu/entries/sovereignty (diakses 12 Nopember 2013).

http://www.jimly.com/pemikiran/view/17 (diakses 30 januari 2014).

http://www.ura.gov.sg (diakses 24 Januari 2014).

\section{Peraturan}

Undang-Undang Dasar Negara Republik Indonesia Tahun 1945.

Undang-Undang Nomor 53 Tahun 1999 tentang tentang Pembentukan Kabupaten Pelalawan, Kabupaten Rokan Hulu, Kabupaten Rokan Hilir, Kabupaten Siak, Kabupaten Karimun, Kabupaten Natuna, Kabupaten Kuantan Singingi, dan Kota Batam.

Undang-Undang Nomor 32 Tahun 2004 tentang Pemerintahan Daerah.

Undang-Undang Nomor 44 Tahun 2007 tentang Penetapan Peraturan Pemerintah Pengganti Undang-Undang Nomor 36 Tahun 2000 tentang Perdagangan Bebas dan Pelabuhan Bebas.

Peraturan Pemerintah Pengganti Undang-Undang Nomor 36 Tahun 2000 tentang Perdagangan Bebas dan Pelabuhan Bebas.

Peraturan Pemerintah Nomor 46 Tahun 2007 tentang Kawasan Perdagangan Bebas dan Pelabuhan Bebas Batam.

Keputusan Presiden Nomor 65 Tahun 1970 tentang Pelaksanaan Proyek Pembangunan Pulau Batam. 
Keputusan Presiden Nomor 74 Tahun 1971 tentang Pengembangan Pembangunan PulauBatam.

Keputusan Presiden Nomor 41 Tahun 1973 tentang Daerah Industri Batam.

Keputusan Menteri Dalam Negeri Nomor 43 Tahun 1977 tentang Pengelolaan dan Penggunaan Tanah di Daerah Industri Pulau Batam. 